\title{
An online solid-phase extraction-liquid chromatography-tandem mass spectrometry method to study the presence of thyronamines in plasma and tissue and their putative conversion from ${ }^{13} \mathrm{C}_{6}$-thyroxine
}

\author{
M T Ackermans ${ }^{1}$, L P Klieverik ${ }^{2}$, P Ringeling ${ }^{3}$, E Endert ${ }^{1}$, A Kalsbeek ${ }^{2,4}$ and E Fliers ${ }^{2}$ \\ ${ }^{1}$ Laboratory of Endocrinology, F2-131.1., Department of Clinical Chemistry and ${ }^{2}$ Department of Endocrinology and Metabolism, Academic Medical Center, \\ University of Amsterdam, Meibergdreef 9, 1105 AZ Amsterdam, The Netherlands \\ ${ }^{3}$ Spark Holland, P. de Keyserstraat 8, 7825 VE, Emmen, The Netherlands \\ ${ }^{4}$ Netherlands Institute for Neuroscience, Meibergdreef 47, 1105 BA, Amsterdam, The Netherlands \\ (Correspondence should be addressed to M T Ackermans; Email: m.t.ackermans@amc.uva.nl)
}

\begin{abstract}
Thyronamines are exciting new players at the crossroads of thyroidology and metabolism. Here, we report the development of a method to measure 3-iodothyronamine $\left(\mathrm{T}_{1} \mathrm{AM}\right)$ and thyronamine $\left(\mathrm{T}_{0} \mathrm{AM}\right)$ in plasma and tissue samples. The detection limit of the method was $0.25 \mathrm{nmol} / \mathrm{l}$ in plasma and $0.30 \mathrm{pmol} / \mathrm{g}$ in tissue both for $\mathrm{T}_{1} \mathrm{AM}$ and for $\mathrm{T}_{0} \mathrm{AM}$. Using this method, we were able to demonstrate $T_{1} A M$ and $\mathrm{T}_{0} \mathrm{AM}$ in plasma and liver from rats treated with synthetic thyronamines. Although we demonstrated the in vivo conversion of ${ }^{13} \mathrm{C}_{6}$-thyroxine $\left({ }^{13} \mathrm{C}_{6}-\mathrm{T}_{4}\right)$ to ${ }^{13} \mathrm{C}_{6}-3,5$, $3^{\prime}$-triiodothyronine, we did not detect ${ }^{13} \mathrm{C}_{6}-\mathrm{T}_{1} \mathrm{AM}$ in plasma
\end{abstract}

or brain samples of rats treated with ${ }^{13} \mathrm{C}_{6}-\mathrm{T}_{4}$. Surprisingly, our method did not detect any endogenous $T_{1} A M$ or $T_{0} A M$ in plasma from vehicle-treated rats, nor in human plasma or thyroid tissue. Although we are cautious to draw general conclusions from these negative findings and in spite of the fact that insufficient sensitivity of the method related to extractability and stability of $\mathrm{T}_{0} \mathrm{AM}$ cannot be completely excluded at this point, our findings raise questions on the biosynthetic pathways and concentrations of endogenous $\mathrm{T}_{1} \mathrm{AM}$ and $\mathrm{T}_{0} \mathrm{AM}$.

Journal of Endocrinology (2010) 206, 327-334

\section{Introduction}

Thyronamines are structural homologs of thyroid hormones (see Fig. 1). In the early 1970s, Dr M Dratman et al. (Dratman 1974) speculated about their putative biosynthesis and action. Cody et al. (1984) described the molecular structure and biochemical activity of 3,5, $3^{\prime}$-triiodothyronamine $\left(\mathrm{T}_{3} \mathrm{AM}\right)$ in 1984. It was, however, not until 2004 that Scanlan et al. (2004) showed a major physiological role for thyronamines based upon elegant experiments in rodents. Systemic administration of 3-iodothyronamine ( $\left.\mathrm{T}_{1} \mathrm{AM}\right)$ and, to a lesser extent, of thyronamine $\left(\mathrm{T}_{0} \mathrm{AM}\right)$ induces profound metabolic and cardiac effects including bradycardia, hypothermia, and hyperglycemia (Scanlan et al. 2004, Braulke et al. 2008, Zucchi et al. 2008, Dhillo et al. 2009, Klieverik et al. 2009). Both in vitro and in vivo studies have proposed potential receptors for thyronamines, i.e. the trace amine-associated receptor 1 (Hart et al. 2006, Grandy 2007, Tan et al. 2009, Panas et al. 2010) and adrenergic receptor $\alpha 2$ (Regard et al. 2007). Furthermore, studies have been published addressing intra-cellular transport (Ianculescu et al. 2009) and metabolism (Piehl et al. 2008b, Wood et al. 2009) of thyronamines. We recently reported that both $\mathrm{T}_{1} \mathrm{AM}$ and $\mathrm{T}_{0} \mathrm{AM}$ can act in the central nervous system to modulate glucose metabolism
(Klieverik et al. 2009). These findings prompted us to develop an online solid-phase extraction (SPE)-liquid chromatography (LC)-tandem mass spectrometry method (XLC-MS) to study the bioavailability of thyronamines in plasma and tissues including the brain and the thyroid gland, as well as to study their hypothesized formation from thyroxine $\left(\mathrm{T}_{4}\right)$ using stably labeled ${ }^{13} \mathrm{C}_{6}-\mathrm{T}_{4}$.

\section{Materials and Methods}

Plasma and tissue samples

We used heparinized plasma samples of thyronamine-treated (i.p. bolus of either $50 \mathrm{mg} / \mathrm{kg} \mathrm{T}$ AM or $50 \mathrm{mg} / \mathrm{kg} \mathrm{T}$ AM in $500 \mu \mathrm{l})$ or vehicle-treated (i.p. bolus of $500 \mu \mathrm{l}$ saline) euthyroid, adult Wistar rats $(n=6)$ that participated in the studies published previously (Klieverik et al. 2008, 2009). Moreover, plasma, hypothalamus, and neocortex samples of rats $(n=2$ per dose) treated with ${ }^{13} \mathrm{C}_{6}-\mathrm{T}_{4}$ were analyzed to investigate whether $\mathrm{T}_{1} \mathrm{AM}$ is formed from $\mathrm{T}_{4}$. These rats had been equipped with a s.c. osmotic minipump delivering ${ }^{13} \mathrm{C}_{6}-\mathrm{T}_{4}$ for a period of 10 days (Alzet 2ml2, Durect Corp., Cupertino, CA, USA; flow rate $5 \mu \mathrm{l} / \mathrm{h}$; dose: vehicle, $0 \cdot 44,1 \cdot 75$, and $20 \mu \mathrm{g} / 100 \mathrm{~g}$ body weight per day; Klieverik et al. 2008). Furthermore, we studied 
<smiles>NC(Cc1cc(I)c(Oc2cc(I)c(O)c(I)c2)c(I)c1)C(=O)O</smiles>
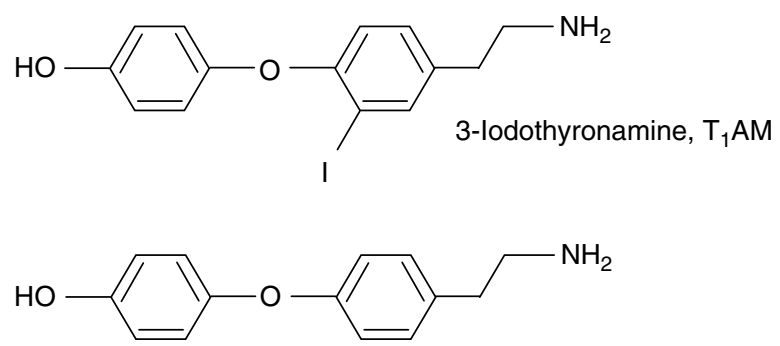

Thyronamine, $\mathrm{T}_{0} \mathrm{AM}$

Figure 1 Structural formulae of $T_{4}, T_{1} A M$, and $T_{0} A M$.

human heparin plasma samples and serum $(n=8)$ taken from healthy volunteers by venipuncture. Finally, we studied human thyroid tissue specimens $(n=2)$ obtained from the thyroid tissue bank in the Academic Medical Center of the University of Amsterdam. As a positive control for the extraction of thyronamines from tissue, we used $(n=2)$ liver samples from the $\mathrm{T}_{1} \mathrm{AM}$ - and $\mathrm{T}_{0} \mathrm{AM}$-treated rats. All the plasma and tissue samples were frozen immediately and thawed only once. All experiments were performed in accordance with the guidelines of either the Medical Ethics Committee of the Academic Medical Center in Amsterdam or the Animal Care Committee of the Royal Netherlands Academy of Arts and Sciences.

\section{Chemicals}

Stock solutions of $10 \mathrm{mM} \mathrm{T}_{0} \mathrm{AM}, \mathrm{T}_{1} \mathrm{AM}, \mathrm{d}_{4}-\mathrm{T}_{1} \mathrm{AM}$, and ${ }^{13} \mathrm{C}_{6}-\mathrm{T}_{1} \mathrm{AM}$ in dimethyl sulfoxide (DMSO) were kindly supplied by Dr T S Scanlan and Dr D K Grandy (Oregon Health and Science University, Portland, USA). Proteinase K, recombinant, PCR grade, and PBS, SDS, and TRIS were obtained from Roche. Coomassie Brilliant Blue G-250, ammonium persulfate, tetramethylethylenediamine, acrylamide/bisacrylamide, and the Protein Plus Marker were obtained from Bio-Rad. ApoA1/ApoB calibrator was obtained form Abbott Diagnostics (Abbott Park). All other chemicals were obtained from Merck.

\section{Recovery experiments}

The recovery of the SPE was tested by comparing peak areas of identical injections of $T_{1} A M, T_{0} A M$, and $d_{4}-T_{1} A M$ with and without $\operatorname{SPE}(n=10)$. In order to test the recovery of the sample pretreatment including the stability of $\mathrm{T}_{1} \mathrm{AM}$ and $\mathrm{T}_{0} \mathrm{AM}$ during the procedure, we processed human plasma and human thyroid after adding $\mathrm{T}_{1} \mathrm{AM}$ and $\mathrm{T}_{0} \mathrm{AM}$ to the sample. For the plasma samples, $10 \mu \mathrm{l}$ of a mix of $1 \mu \mathrm{mol} / 1 \mathrm{~T}_{1} \mathrm{AM}$ and
$\mathrm{T}_{0} \mathrm{AM}$ in $\mathrm{PBS}$ were added to $100 \mu \mathrm{l}$ plasma. Plasma was vortexed and processed as unspiked plasma. For the thyroid tissue samples, the same amount of $\mathrm{T}_{1} \mathrm{AM}$ and $\mathrm{T}_{0} \mathrm{AM}$ was added to $100 \mathrm{mg}$ tissue at the same time as the internal standard (IS). The recovery was calculated as the concentration of thyronamines measured divided by the concentration added.

\section{Sample pretreatment}

All quantitative analyses were carried out using the IS method using stable isotope-labeled $\mathrm{T}_{1} \mathrm{AM}$. As IS, $\mathrm{d}_{4}-\mathrm{T}_{1} \mathrm{AM}(1 \mu \mathrm{M}$ in PBS) was used. In this molecule, four hydrogen atoms are replaced by four deuterium atoms. As hydrogen and deuterium are isotopes of the same element, $\mathrm{d}_{4}-\mathrm{T}_{1} \mathrm{AM}$ and $\mathrm{T}_{1} \mathrm{AM}$ act similarly both biologically and analytically. However, due to the higher atomic mass of deuterium compared with hydrogen, the molecular weight of $d_{4}-T_{1} A M$ is 4 mass units higher than that of $T_{1} A M$ enabling the distinction between the two molecules by mass spectrometry. No $d_{4}-T_{1} A M$ was added to the samples that were used to study the conversion from ${ }^{13} \mathrm{C}_{6}-\mathrm{T}_{4}$ to ${ }^{13} \mathrm{C}_{6}-\mathrm{T}_{1} \mathrm{AM}$.

Plasma samples Ten microliters IS were added to $100 \mu \mathrm{l}$ plasma. Samples were incubated overnight $(15-17 \mathrm{~h})$ at $37^{\circ} \mathrm{C}$ with $20 \mu \mathrm{l}$ proteinase $\mathrm{K}(100 \mathrm{mg} / \mathrm{ml}$ in distilled water $)$. Thereafter, the sample was centrifuged $(3 \mathrm{~min}$ at $16000 \mathrm{~g}$ ). Five microliters of the supernatant were diluted 20 times with distilled water. This dilution was used for the measurement of protein fragments using SDS-PAGE and Coomassie Brilliant Blue coloring. To another $100 \mu \mathrm{l}$ of the supernatant, $150 \mu \mathrm{l}$ of $0 \cdot 1 \%$ formic acid were added. The sample was placed at $4{ }^{\circ} \mathrm{C}$ until analysis with XLC-MS.

Tissue samples Ten microliters IS and $3 \mathrm{ml}$ prechilled $\mathrm{KH}_{2} \mathrm{PO}_{4}$ solution $(100 \mathrm{mM}$ at $\mathrm{pH}$ 6) were added to ca. $100 \mathrm{mg}$ tissue. The tissue was ground until it was devoid of visible tissue fragments. Six milliliters of chilled acetic acetone ( $5 \mu \mathrm{l}$ of $37 \% \mathrm{HCl}$ in $100 \mathrm{ml}$ acetone) were added. In order to complete denaturation, the sample was placed on ice for $10 \mathrm{~min}$. After centrifugation $(10 \mathrm{~min}$ at $4000 \mathrm{~g}$ ), the supernatant was transferred to a clean tube and evaporated to dryness followed by the addition of $300 \mu \mathrm{l}$ of $0 \cdot 1 \%$ formic acid. The supernatant obtained after centrifugation $(5 \mathrm{~min}$ at $4000 \mathrm{~g}$ ) was placed at $4{ }^{\circ} \mathrm{C}$ until XLC-MS analysis.

Calibration solutions Serial dilutions of the stock solutions of $\mathrm{T}_{1} \mathrm{AM}$ and $\mathrm{T}_{0} \mathrm{AM}(10 \mathrm{mM}$ in DMSO) at 1,5 , $10,20,30,40$, and $50 \mathrm{nmol} / 1$ were prepared in $0 \cdot 1 \%$ formic acid. For XLC-MS, $100 \mu \mathrm{l}$ of each calibration standard were pipetted in a deep well plate. To each well, $10 \mu \mathrm{l}$ IS and $140 \mu \mathrm{l}$ $0 \cdot 1 \%$ formic acid were added. Before the deep well plate was put into the autosampler it was covered, vortexed, and centrifuged $(2 \mathrm{~min}$ at $1000 \mathrm{~g}$ ) to make sure that all the samples were well mixed, and that no air bubbles were left in the wells. For the linearity check, calibration was extended with concentrations of 100 and $200 \mathrm{nmol} / 1 \mathrm{~T}_{1} \mathrm{AM}$ and $\mathrm{T}_{0} \mathrm{AM}$. 
XLC-MS procedure

Instrumentation For the analysis, we used a Symbiosis Pharma System (Spark Holland, Emmen, The Netherlands) coupled to a Quattro Premier XE tandem MS system (Waters, Milford, MA, USA).

Solid-phase extraction SPE was achieved on an OASIS WCX cartridge $(10 \times 1 \mathrm{~mm}, 30 \mu \mathrm{m}$, Waters). The cartridge was conditioned with $1 \mathrm{ml}$ acetonitrile and equilibrated with $1 \mathrm{ml}$ of $10 \mathrm{mM}$ ammonium acetate at $\mathrm{pH}$ 8:methanol (90:10). $100 \mu \mathrm{l}$ of the sample were loaded on the cartridge using $1 \mathrm{ml}$ of $10 \mathrm{mM}$ ammonium acetate at $\mathrm{pH}$ 8:methanol (90:10), and the cartridge was washed with another $1 \mathrm{ml}$ of this solution. The purified thyronamines were eluted using the highpressure dispenser in focusing mode. During focusing, the analytes of interest are eluted from the cartridge with $200 \mu \mathrm{l}$ $\mathrm{H}_{2} \mathrm{O}$ :acetonitrile:acetic acid $(50 / 50 / 0 \cdot 6)$. Post-cartridge addition of aqueous solvent delivered by the LC pump reduces the percentage of organic solvent used for cartridge elution before the analytes reach the LC column. As a consequence, the analytes are trapped at the head of the column. After this focusing step, the LC gradient is started in order to separate the analytes on the LC column.

Liquid chromatography The LC method was adapted from Piehl et al. (2008a). Briefly, the sample was separated on a Phenomenex Synergi Polar-RP $80 \AA$, $4 \mu \mathrm{m}$ particles, $50 \times 2 \mathrm{~mm}$ (Phenomenex, Maarssenbroek, The Netherlands) using gradient elution. Flow was $0.20 \mathrm{ml} / \mathrm{min}$. The composition of mobile phase A was $\mathrm{H}_{2} \mathrm{O}$ :acetonitrile:acetic acid $(95 / 5 / 0 \cdot 6)$, and the composition of mobile phase $B$ was $\mathrm{H}_{2} \mathrm{O}$ :acetonitrile:acetic acid $(5 / 95 / 0 \cdot 6)$. Gradient program was as follows: $100 \% \mathrm{~A}$ for $2 \mathrm{~min}$ (high pressure dispenser focusing time), thereafter from $90 \% \mathrm{~A}$ to $10 \% \mathrm{~A}$ in $2.5 \mathrm{~min}$, hold for $1 \mathrm{~min}$ at $10 \% \mathrm{~A}$, and re-equilibration at $90 \% \mathrm{~A}$ for $3 \mathrm{~min}$. Total runtime was $8.5 \mathrm{~min}$.

Mass spectrometry We used ionization in the ESI + mode with the following parameters: capillary voltage, $3.00 \mathrm{kV}$; cone voltage, $25.00 \mathrm{~V}$; extractor, $3.00 \mathrm{~V}$; RF Lens, $0.3 \mathrm{~V}$; source temperature, $140{ }^{\circ} \mathrm{C}$, desolvation temperature, $300{ }^{\circ} \mathrm{C}$. Cone gas flow was $200 \mathrm{l} / \mathrm{h}$, and desolvation gas flow was $1000 \mathrm{l} / \mathrm{h}$. T 0 AM, T $\mathrm{AM}$, and $\mathrm{d}_{4}-\mathrm{T}_{1} \mathrm{AM}$ were measured in the multiple reaction monitoring (MRM) mode using the following MRM transitions: $\mathrm{T}_{0} \mathrm{AM} 230>109$ and $230>213, \mathrm{~T}_{1} \mathrm{AM} 356>212$ and $356>339$, and $\mathrm{d}_{4}-\mathrm{T}_{1} \mathrm{AM}$ $360>216$ and $360>343$. For the quantification, we used the MassLynx software (Version 4.1, Waters).

Thyroid hormone measurement Owing to the structural homology of thyronamines and thyroid hormones, the above-mentioned method, although not optimized, can also be used to detect thyroid hormones. For qualitative analyses of the stably labeled compounds, the following MRM transitions were measured: ${ }^{13} \mathrm{C}_{6}-\mathrm{T}_{1} \mathrm{AM} 362>218$ and $362>345,{ }^{13} \mathrm{C}_{6}-\mathrm{T}_{4} 783>738$, and ${ }^{13} \mathrm{C}_{6}-\mathrm{T}_{3} 658>612$. As no ${ }^{13} \mathrm{C}_{6}-\mathrm{T}_{3}$ standard was available, the retention time of $\mathrm{T}_{3}$ was determined using unlabeled $\mathrm{T}_{3}$ with MRM 652>606. Thyroid hormone status of the rats was evaluated by measuring $\mathrm{T}_{4}, \mathrm{~T}_{3}$ and $\mathrm{TSH}$ concentrations in the plasma samples using immunoassays as reported previously (Klieverik et al. 2009).

\section{Analytical characterization of the method}

Linearity and precision We established an estimate of the linearity and precision based upon the protocols of the Committee of Clinical and Laboratory Standards Institute (CLSI) of the US using the EP Evaluator 8 software (D.G. Rhoads Associates, South Burlington, VT, USA).

Limit of detection To estimate the limit of detection (LOD), calibration standards were made with concentrations of $0.08,0 \cdot 17,0.25,0.33,0.42$, and $0.50 \mathrm{nmol} / 1$. These samples were injected, and the signal to noise ratio was determined for the different peaks. The LOD was set to the lowest concentration with the signal to noise ratio $>10$.

\section{Protein electrophoresis by SDS-PAGE}

We analyzed the protein fragments of the plasma samples using 12\% SDS-PAGE with a Laemmli buffer at $\mathrm{pH} 8 \cdot 3-8 \cdot 5$. The marker used was the Protein Plus Precision Marker. After electrophoresis, gels were stained overnight at room temperature using Coomassie Brilliant Blue G-250 $(3 \mathrm{mg} / \mathrm{ml})$ in $10 \%$ acetic acid. Gels were destained in $10 \%$ acetic acid solution in 4-8 h. To study the degradation of ApoB, we ran two human plasma samples untreated or treated

Table 1 Recovery experiments

\begin{tabular}{|c|c|c|}
\hline $\mathrm{T}_{1} \mathrm{AM}$ & $\mathrm{T}_{0} \mathrm{AM}$ & $\mathrm{d}_{4}-\mathrm{T}_{1} \mathrm{AM}$ \\
\hline $52540(2 \%)$ & $64618(1 \%)$ & $65983(2 \%)$ \\
\hline $45268(3 \%)$ & $47229(3 \%)$ & $58257(2 \%)$ \\
\hline $87 \%$ & $73 \%$ & $89 \%$ \\
\hline $96 \%$ & $103 \%$ & \\
\hline $89 \%$ & $140 \%$ & \\
\hline
\end{tabular}

(A) SPE recovery $(n=10)$

Area without SPE (cv)

Area with SPE (cv)

Recovery

(B) Sample pretreatment recovery $(n=2)$

Human plasma

Human thyroid

www.endocrinology-journals.org 
A

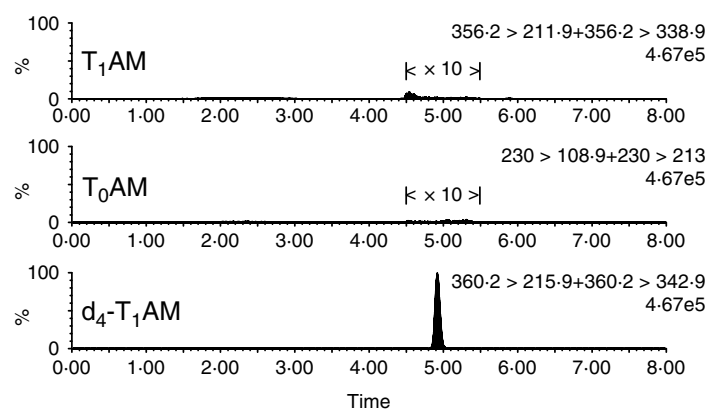

C
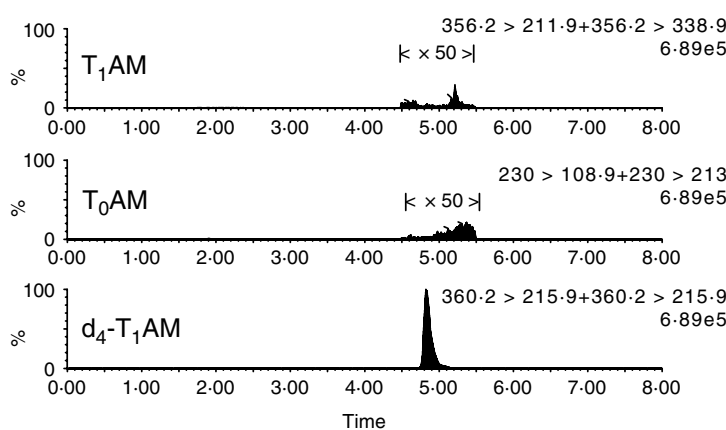

$\mathrm{E}$
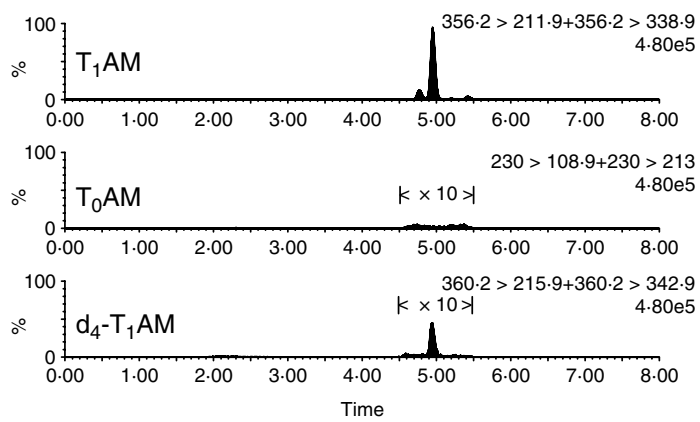

G
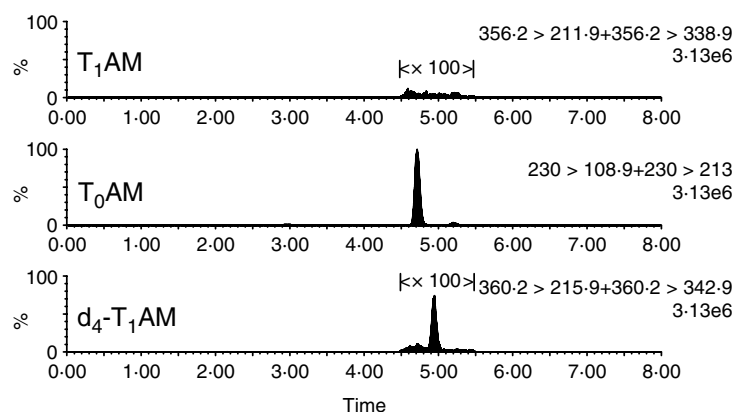

B

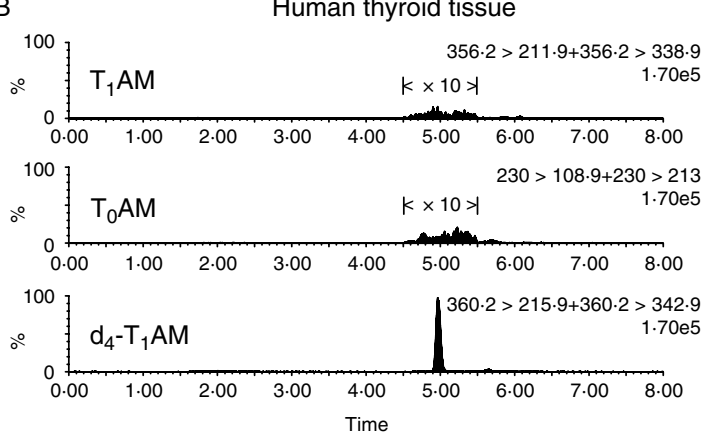

D

Vehicle rat liver tissue

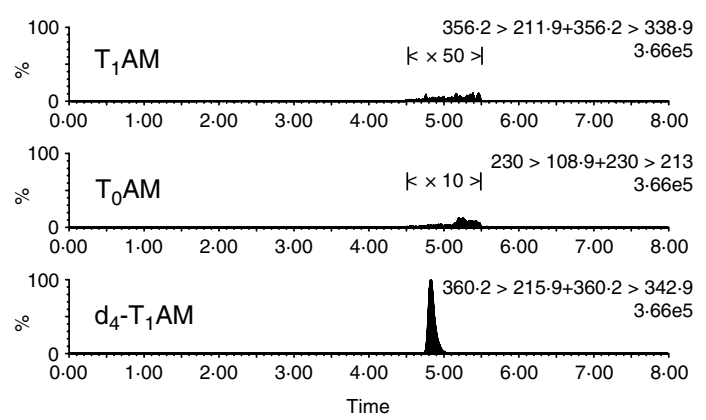

$\mathrm{F}$

$\mathrm{T}_{1} \mathrm{AM}$-treated rat liver tissue

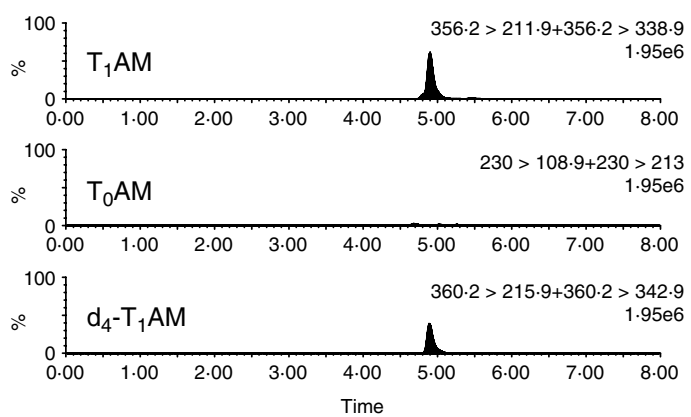

$\mathrm{H}$

$\mathrm{T}_{0} \mathrm{AM}$-treated rat liver tissue
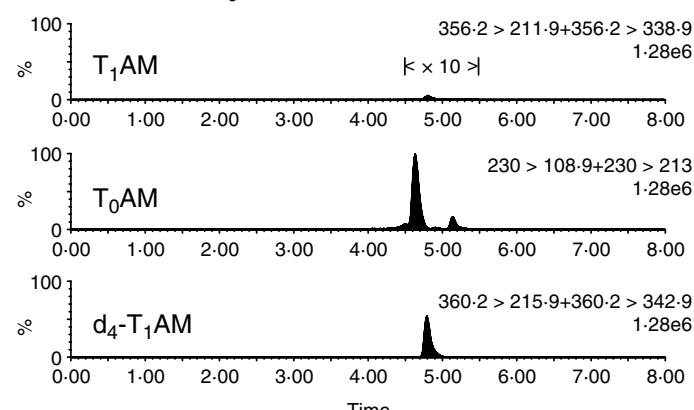

Figure 2 Representative chromatograms of human (A) plasma and (B) thyroid tissue, vehicle-treated rat (C) plasma and (D) liver tissue, $T_{1} A M$-treated rat $(E)$ plasma and $(F)$ liver tissue, and $T_{0} A M$-treated rat $(G)$ plasma and $(H)$ liver tissue. In some cases, the part of the chromatogram where $\mathrm{T}_{1} \mathrm{AM}$ or $\mathrm{T}_{0} \mathrm{AM}$ should show up is magnified by the factor indicated. Note the presence of $\mathrm{T}_{1} \mathrm{AM}$ or $\mathrm{T}_{0} \mathrm{AM}$ in samples from thyronamine-treated rats and their absence in other samples. 
with the proteinase $\mathrm{K}$ protocol using 4\% SDS-PAGE and silver staining as described by Furbee \& Fless (1996). As a marker, we used the ApoA1/ApoB calibrator from Abbott Diagnostics.

\section{Results}

\section{Recovery experiments}

The results of the recovery experiments are given in Table 1. As can be observed in the table, the recovery of the SPE was 87,73 , and $89 \%$ for $\mathrm{T}_{1} \mathrm{AM}, \mathrm{T}_{0} \mathrm{AM}$, and $\mathrm{d}_{4}-\mathrm{T}_{1} \mathrm{AM}$ respectively. The recovery of the sample pretreatment was $95 \%$ for $\mathrm{T}_{1} \mathrm{AM}$ and $122 \%$ for $\mathrm{T}_{0} \mathrm{AM}$.

\section{Analytical characterization of the method}

Linearity The accuracy tests were successful. Using the measuring range of 1-50 nmol/1, the maximum deviation for a mean recovery from $100 \%$ was $4 \cdot 3 \%$ for $\mathrm{T}_{1} \mathrm{AM}$ and $5 \cdot 9 \%$ for $\mathrm{T}_{0} \mathrm{AM}$. For both the components, 7 out of 7 mean recoveries were accurate within the allowable systematic error of $6 \%$, and 14 out of 14 results were accurate within the allowable total error of $20 \%$. All results were linear. In the range of 5-200 nmol/1, the maximum deviation for a mean recovery was $5 \cdot 4 \%$ for $\mathrm{T}_{1} \mathrm{AM}$ and $9 \cdot 4 \%$ for $\mathrm{T}_{0} \mathrm{AM}$. For both the components, 6 out of 6 recoveries were accurate within the allowable systematic error of $6 \%$, and 12 out of 12 results were accurate within the allowable total error of $20 \%$.

Precision For the calibration standard of $2 \cdot 5 \mathrm{nmol} / 1$, the coefficient of variation was $1 \cdot 4 \%$ for $\mathrm{T}_{1} \mathrm{AM}$ and $6 \cdot 1 \%$ for $\mathrm{T}_{0} \mathrm{AM}$ based upon the variation in response values (area $\mathrm{T}_{1} \mathrm{AM}$ over area $\mathrm{d}_{4}-\mathrm{T}_{1} \mathrm{AM}$ ) of 12 measurements in one run.

Limit of detection In the $0 \cdot 08 \mathrm{nmol} / 1$ sample, the signal to noise ratio was $7 \cdot 03$ for $\mathrm{T}_{1} \mathrm{AM}$ and $9 \cdot 25$ for $\mathrm{T}_{0} \mathrm{AM}$ (both $<10)$. In the $0.17 \mathrm{nmol} / 1$ sample, the values were 13.72 and $17 \cdot 06$ respectively implying a LOD of $0 \cdot 10 \mathrm{nmol} / 1 \mathrm{referring}$ to the concentration in the well. Considering the dilutions for the plasma and tissue samples, we inferred a LOD of $0.25 \mathrm{nmol} / 1$ in plasma and $0.30 \mathrm{pmol} / \mathrm{g}$ in tissue both for $\mathrm{T}_{1} \mathrm{AM}$ and for $\mathrm{T}_{0} \mathrm{AM}$.

Plasma and tissue samples Figures shown are representative for the various groups, i.e. only one chromatogram of human plasma is shown, but the other seven samples were very similar. Moreover, we did not observe any difference between heparinized plasma samples and serum samples. Figure 2 shows representative chromatograms of various plasma and tissue samples. $\mathrm{T}_{1} \mathrm{AM}$ and $\mathrm{T}_{0} \mathrm{AM}$ were detected in the thyronamine-treated animals. Plasma concentrations of $\mathrm{T}_{1} \mathrm{AM}$ in $\mathrm{T}_{1} \mathrm{AM}$-treated rats and plasma concentrations of $\mathrm{T}_{0} \mathrm{AM}$ in $\mathrm{T}_{0} \mathrm{AM}$-treated rats were $>200 \mathrm{nmol} / \mathrm{l}$. In the liver samples, concentrations of $\mathrm{T}_{1} \mathrm{AM}$ and $\mathrm{T}_{0} \mathrm{AM}$ were $>600 \mathrm{pmol} / \mathrm{g}$ tissue, yielding a sample higher than $200 \mathrm{nmol} / \mathrm{l}$ for the
XLC-MS injection. We did not detect $\mathrm{T}_{1} \mathrm{AM}$ or $\mathrm{T}_{0} \mathrm{AM}$ above the LOD in human or vehicle-treated rat plasma, nor in the thyroid tissue samples. In Fig. 3A, we show that the proteinase $\mathrm{K}$ treatment of our plasma samples effectively degraded the protein using SDS-PAGE and Coomassie Brilliant Blue staining. Figure $3 \mathrm{~B}$ shows that also larger proteins, including $\mathrm{ApoB}$, are degraded in our proteinase $\mathrm{K}$ protocol. In Fig. 4, we show the results of the conversion study. Panel A shows the chromatograms of a standard containing ${ }^{13} \mathrm{C}_{6}-\mathrm{T}_{1} \mathrm{AM}, \mathrm{T}_{3}$, and ${ }^{13} \mathrm{C}_{6}-\mathrm{T}_{4}$, and panel $\mathrm{B}$ shows the chromatograms of a blank injection of $100 \mu \mathrm{l}$ distilled water, and panels $\mathrm{C}-\mathrm{E}$ show the chromatograms of plasma, hypothalamus, and neocortex of a ${ }^{13} \mathrm{C}_{6}-\mathrm{T}_{4}$-treated rat.
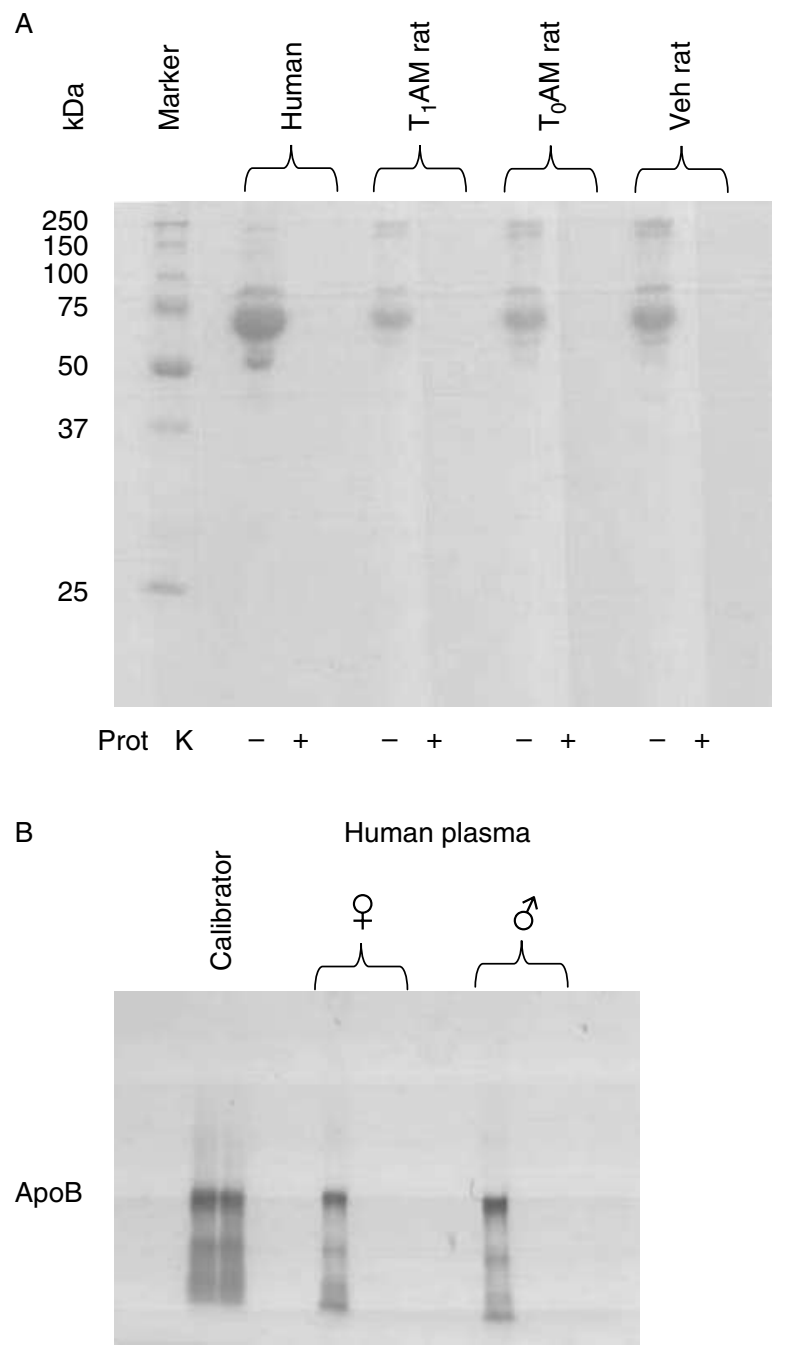

Figure 3 Panel A, representative Coomassie Brilliant Blue-stained $12 \%$ protein gel for plasma samples before and after treatment with proteinase $\mathrm{K}$ showing complete degradation of the proteins present in the plasma. Panel B, representative silver-stained $4 \%$ protein gel for human plasma samples before and after treatment with proteinase $\mathrm{K}$ showing complete degradation of the lager proteins present in the plasma. 
A

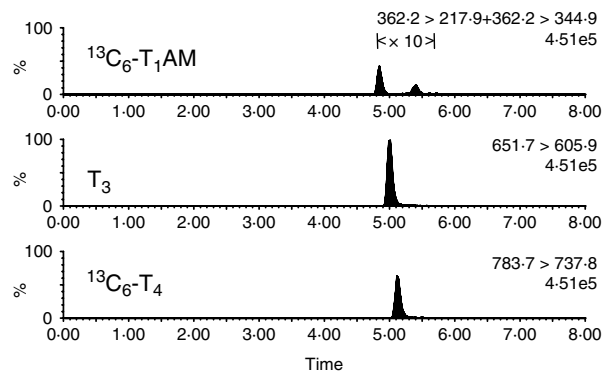

B

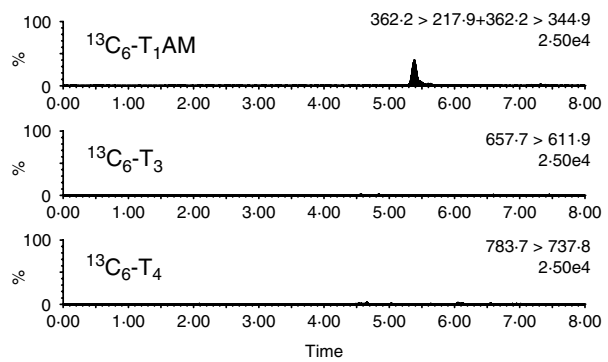

C
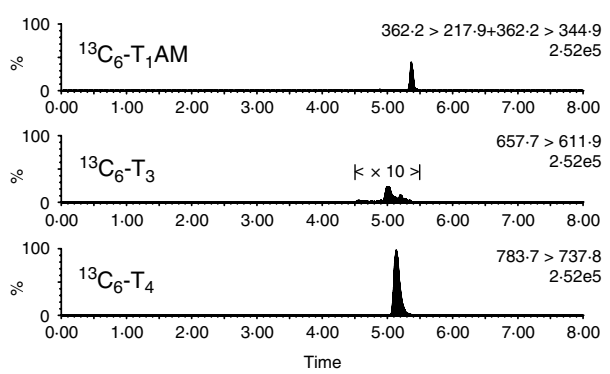

D
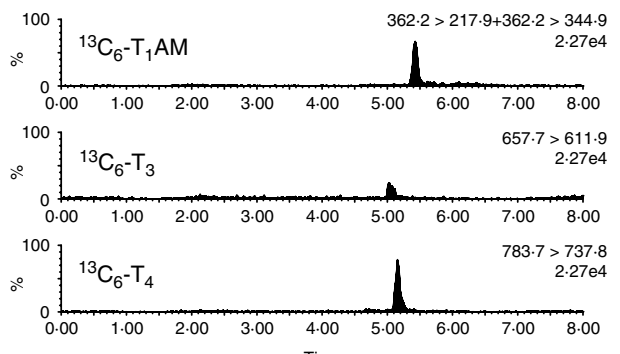

E
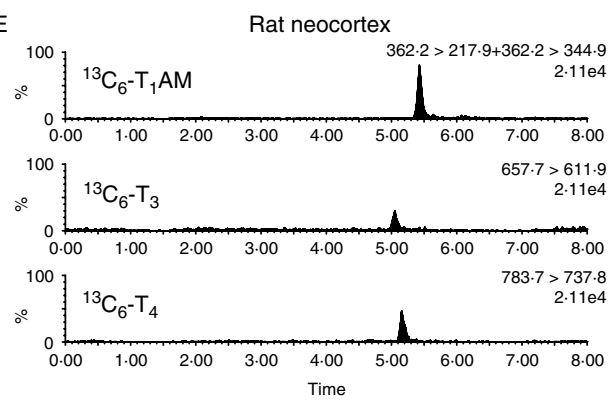

Plasma $\mathrm{T}_{4}, \mathrm{~T}_{3}$, and TSH concentrations for the different doses of $\mathrm{T}_{4}$ are given in Table 2. Although we detected both ${ }^{13} \mathrm{C}_{6}-\mathrm{T}_{4}$ and ${ }^{13} \mathrm{C}_{6}-\mathrm{T}_{3}$ in the samples of the ${ }^{13} \mathrm{C}_{6}-\mathrm{T}_{4}$-treated rats, we did not detect ${ }^{13} \mathrm{C}_{6}-\mathrm{T}_{1} \mathrm{AM}$ in any of the samples. As can be observed in panel $\mathrm{A}$, two peaks are clearly visible with MRM 362> 218 and $362>345$ (the ${ }^{13} \mathrm{C}_{6}-\mathrm{T}_{1}$ AM channel). In XLC-MS, there are two ways to identify a compound: the MRM and the retention time, which is specific for a component in a chromatographic system. The experiments with $\mathrm{T}_{1} \mathrm{AM}$ and ${ }^{13} \mathrm{C}_{6}-\mathrm{T}_{1} \mathrm{AM}$ standards and samples from $\mathrm{T}_{1} \mathrm{AM}$-treated rats showed that in our chromatographic system the retention time of $\mathrm{T}_{1} \mathrm{AM}$ and ${ }^{13} \mathrm{C}_{6}-\mathrm{T}_{1} \mathrm{AM}$ is $4.8 \mathrm{~min}$ (Figs $2 \mathrm{E}$ and $\mathrm{F}$, and $4 \mathrm{~A}$ ). Based upon the retention time, the peak at $5.5 \mathrm{~min}$ does not represent ${ }^{13} \mathrm{C}_{6}-\mathrm{T}_{1} \mathrm{AM}$ but another compound showing the same MRM, but with different chromatographic behavior to ${ }^{13} \mathrm{C}_{6}-\mathrm{T}_{1} \mathrm{AM}$. Theoretically, it could represent a ${ }^{13} \mathrm{C}_{6}$-labeled thyronamine with more than one iodine molecule, which is abolished in the ionization. However, as this peak was also present after injecting only water into the system (see Fig. 4, panel B), we concluded that it originates from one of the chemicals used for mobile phases and/or SPE solvents, thus representing an artifact. Looking closely at the MRM 362>218 and 362> 345 in the panels of the plasma, hypothalamus, and neocortex of the ${ }^{13} \mathrm{C}_{6}$-treated rat (Fig. 4, panels C, D, and E), the only peak present is the artifact peak at retention time of $5.5 \mathrm{~min}$. In summary, $\mathrm{T}_{1} \mathrm{AM}$ and $\mathrm{T}_{0} \mathrm{AM}$ were only present above the LOD in plasma of rats treated with $T_{1} A M$ or $T_{0} A M$ respectively, and we were not able to show any conversion of ${ }^{13} \mathrm{C}_{6}-\mathrm{T}_{4}$ to ${ }^{13} \mathrm{C}_{6}-\mathrm{T}_{1} \mathrm{AM}$ in rat plasma, neocortex, or hypothalamus.

\section{Discussion}

We have developed an analytical method to measure thyronamines in plasma and tissue requiring minimal sample pretreatment, due to the fact that the method uses online SPE. Compared with offline methods. this method has the advantages that manual sample preparation and solvent usage are minimized. In addition, an online method is more robust as human error is minimized. Using $100 \mu \mathrm{l}$ plasma or $100 \mathrm{mg}$ tissue, the detection limit of the method is $0.25 \mathrm{nmol} / 1$ in plasma and $0.30 \mathrm{pmol} / \mathrm{g}$ in tissue both for $\mathrm{T}_{1} \mathrm{AM}$ and for $\mathrm{T}_{0} \mathrm{AM}$. Using this method, we were able to detect $T_{1} A M$ and $T_{0} A M$ in rats treated with $T_{1} A M$ and $T_{0} A M$ respectively. The concentration of these thyronamines

Figure 4 Representative chromatograms of (A) standard $6 \mathrm{nmol} / \mathrm{l}$, (B) blank injection of $100 \mu \mathrm{l}$ distilled water, and (C) plasma, (D) hypothalamus, and (E) neocortex of a ${ }^{13} \mathrm{C}_{6}-\mathrm{T}_{4}$-treated rat. As can be observed in panels $\mathrm{C}-\mathrm{E}$, a peak representing ${ }^{13} \mathrm{C}_{6}-\mathrm{T}_{3}$ appears, indicating a ${ }^{13} \mathrm{C}_{6}-\mathrm{T}_{4}$ to ${ }^{13} \mathrm{C}_{6}-\mathrm{T}_{3}$ conversion. Nevertheless, we could not demonstrate the conversion of ${ }^{13} \mathrm{C}_{6}-\mathrm{T}_{4}$ to ${ }^{13} \mathrm{C}_{6}-\mathrm{T}_{1} \mathrm{AM}$ as no peak appears in the ${ }^{13} C_{6}-T_{1} A M$ trace. The peak in the ${ }^{13} C_{6}-T_{1} A M$

chromatograms at $5.5 \mathrm{~min}$ in panels $\mathrm{C}-\mathrm{E}$ represents an artifact, as it is also present in blank injections (see panel $\mathrm{B}$ and text). 
Table 2 Mean $(n=2)$ concentrations of TSH, thyroxine $\left(\mathrm{T}_{4}\right)$, and 3,5,3'-triiodothyronine $\left(\mathrm{T}_{3}\right)$ in plasma of rats treated with ${ }^{13} \mathrm{C}_{6}-\mathrm{T}_{4}$

\begin{tabular}{|c|c|c|c|}
\hline & TSH $(\mathrm{mU} / \mathrm{l})$ & $\mathbf{T}_{\mathbf{4}}(\mathrm{nmol} / \mathrm{l})$ & $\mathbf{T}_{3}(\mathrm{nmol} / \mathrm{l})$ \\
\hline \multicolumn{4}{|c|}{ Dose ${ }^{{ }^{13}} \mathbf{C}_{6}-\mathbf{T}_{\mathbf{4}}$ ( $\mu \mathrm{g} / 100 \mathrm{~g}$ body weight per day) } \\
\hline Vehicle & $2 \cdot 97$ & 82 & $0 \cdot 98$ \\
\hline $0 \cdot 44$ & $0 \cdot 79^{\mathrm{a}}$ & 94 & $1 \cdot 10$ \\
\hline $1 \cdot 75$ & $0 \cdot 59$ & 165 & $1 \cdot 14$ \\
\hline 20 & $<0 \cdot 20$ & 201 & $3 \cdot 34$ \\
\hline
\end{tabular}

${ }^{\mathrm{a}} n=1$.

is above the highest calibration standard. Braulke et al. (2008) showed that in Djungarian hamsters, serum $\mathrm{T}_{1} \mathrm{AM}$ levels were between 50 and $60 \mathrm{nmol} / 13 \mathrm{~h}$ after i.p. injection of $50 \mathrm{mg} / \mathrm{kg}$ $\mathrm{T}_{1} \mathrm{AM}$. Besides the obvious species difference, our plasma samples were pooled samples taken between 5 and $120 \mathrm{~min}$ after injection, making direct comparison between their data and our data very difficult. In spite of the fact that endogenous levels of thyronamines published to date (Braulke et al. 2008, DeBarber et al. 2008, Zucchi et al. 2008) are above our LOD, to our surprise we did not detect any endogenous $\mathrm{T}_{1} \mathrm{AM}$ or $\mathrm{T}_{0} \mathrm{AM}$.

As can be observed in Fig. 3A, the proteinase $\mathrm{K}$ treatment of plasma effectively degraded proteins, making protein binding as an explanation for our negative results regarding endogenous thyronamines very unlikely. ApoB 100, a $550 \mathrm{kDa}$ protein that cannot be separated on a $12 \%$ gel, has been reported at various recent meetings to be the major binding protein for thyronamines. In Fig. 3B, we also show that ApoB is effectively degraded by our proteinase $\mathrm{K}$ treatment using a $4 \%$ SDS-PAGE and silver staining. The observation that the protein binding of thyronamines is effectively abolished by the proteinase $\mathrm{K}$ treatment without degrading the thyronamines follows from the recovery experiment, arguing against instability of the thyronamines during proteinase $\mathrm{K}$ treatment. In addition, we observed $\mathrm{T}_{1} \mathrm{AM}$ and $\mathrm{T}_{0} \mathrm{AM}$ in high concentrations in thyronamine-treated rats, supporting effective proteinase $\mathrm{K}$ treatment. With respect to tissue thyronamines, it could be argued that thyronamines are lost during the sample pretreatment, but again this argument can be refuted by our observations in the liver samples of the thyronamine-treated rats and by the recovery experiment in human thyroid tissue.

Pietsch et al. (2007) showed that thyronamines are substrates of human liver sulfotransferases. Therefore, another reason for the absence of endogenous $\mathrm{T}_{1} \mathrm{AM}$ or $\mathrm{T}_{0} \mathrm{AM}$ in our method could be that they are present as sulfoconjugates. In that case, their molecular weight would be higher, and ionization would be altered so they would not appear in the very specific MRM transitions of the unconjugated thyronamine. However, given the fact that we observe $T_{1} A M$ and $T_{0} A M$ in thyronaminetreated animals in such high concentrations ( $>200 \mathrm{nmol} / 1$ plasma or $>600 \mathrm{pmol} / \mathrm{g}$ tissue), we do not expect the thyronamines to be mainly present as sulfoconjugates.

The biosynthetic pathway of conversion thyroid hormone to thyronamines would require both deiodination and decarboxylation. Piehl et al. (2008b) showed that thyronamines are substrates for the human deiodinases. The decarboxylating enzyme, however, still remains to be identified. Pyridoxal-5-phosphate-dependent aromatic L-amino acid decarboxylase (AADC) is a promising candidate, although Hoefig et al. (2009) recently reported that recombinant human AADC does not efficiently catalyze the decarboxylation of $\mathrm{rT}_{3}$. De novo synthesis of thyronamines would require oxidative coupling of two molecules of tyrosine and aromatic ring iodination, processes that are also involved in the biosynthesis of thyroid hormone. Although there are hints that several organs/tissues are capable of generating some thyroid hormone (Taurog \& Evans 1967, Obregon et al. 1981, Meischl et al. 2008), the thyroid is considered the primary source of generating thyroid hormone. Therefore, if de novo synthesis was substantial, we would expect to find thyronamines in thyroid tissue. However, we did not find any endogenous $\mathrm{T}_{1} \mathrm{AM}$ or $\mathrm{T}_{0} \mathrm{AM}$ in thyroid tissue. In vivo conversion of thyroid hormones has been postulated as a biosynthetic route for thyronamines (Zucchi et al. 2008, Scanlan 2009). To investigate this route, we treated rats with ${ }^{13} \mathrm{C}_{6}-\mathrm{T}_{4}$ for 10 days in different doses. This did not result in the appearance of detectable ${ }^{13} \mathrm{C}_{6}-\mathrm{T}_{1} \mathrm{AM}$, arguing against the biosynthesis of $\mathrm{T}_{0} \mathrm{AM}$ from thyroid hormones under euthyroid or hyperthyroid conditions. In support of in vivo deiodination of stably labeled $\mathrm{T}_{4}$, we were able to detect ${ }^{13} \mathrm{C}_{6}-\mathrm{T}_{3}$ in plasma and brain tissue indicating that the exogenous ${ }^{13} \mathrm{C}_{6}-\mathrm{T}_{4}$ was metabolized.

In conclusion, we have developed a simple and sensitive method to determine $\mathrm{T}_{1} \mathrm{AM}$ and $\mathrm{T}_{0} \mathrm{AM}$ in plasma and tissue samples. Using this method, we could identify $\mathrm{T}_{1} \mathrm{AM}$ and $\mathrm{T}_{0} \mathrm{AM}$ in plasma and liver of thyronamine-treated animals. Unexpectedly, we did not detect any endogenous $\mathrm{T}_{1} \mathrm{AM}$ or $\mathrm{T}_{0} \mathrm{AM}$ in plasma or thyroid tissue samples, nor could we demonstrate the in vivo conversion of ${ }^{13} \mathrm{C}_{6}-\mathrm{T}_{4}$ to ${ }^{13} \mathrm{C}_{6}-\mathrm{T}_{1} \mathrm{AM}$. Although insufficient extraction from plasma or tissue, instability of the thyronamines, or insufficient sensitivity of the method cannot be completely excluded at present, these findings raise questions about the biosynthetic pathways and concentrations of endogenous $\mathrm{T}_{1} \mathrm{AM}$ and $\mathrm{T}_{0} \mathrm{AM}$.

\section{Declaration of interest}

The authors declare that there is no conflict of interest that could be perceived as prejudicing the impartiality of the research reported.

Journal of Endocrinology (2010) 206, 327-334 


\section{Funding}

This research did not receive any specific grant from any funding agency in the public, commercial, or not-for-profit sector.

\section{Acknowledgements}

The authors gratefully acknowledge Prof. Karl Bauer (Leibniz Institute for Age Research - Fritz Lipmann Institute, Jena) and Dr A Boelen (Department of Endocrinology and Metabolism, Academic Medical Center, Amsterdam, The Netherlands) for their stimulating discussions.

\section{References}

Braulke LJ, Klingenspor M, DeBarber A, Tobias SC, Grandy DK, Scanlan TS \& Heldmaier G 2008 3-Iodothyronamine: a novel hormone controlling the balance between glucose and lipid utilisation. Journal of Comparative Physiology. B, Biochemical, Systemic, and Environmental Physiology 178 167-177. (doi:10.1007/s00360-007-0208-x)

Cody V, Meyer T, Dohler KD, Hesch RD, Rokos H \& Marko M 1984 Molecular structure and biochemical activity of 3,5,3'-triiodothyronamine. Endocrine Research 10 91-99. (doi:10.3109/074358084 09035410)

DeBarber AE, Geraci T, Colasurdo VP, Hackenmueller SA \& Scanlan TS 2008 Validation of a liquid chromatography-tandem mass spectrometry method to enable quantification of 3-iodothyronamine from serum. Journal of Chromatography. A 1210 55-59. (doi:10.1016/j.chroma.2008. 09.022)

Dhillo WS, Bewick GA, White NE, Gardiner JV, Thompson EL, Bataveljic A, Murphy KG, Roy D, Patel NA, Scutt JN et al. 2009 The thyroid hormone derivative 3-iodothyronamine increases food intake in rodents. Diabetes, Obesity and Metabolism 11 251-260. (doi:10.1111/ j.1463-1326.2008.00935.x)

Dratman MB 1974 On the mechanism of action of thyroxin, an amino acid analog of tyrosine. Journal of Theoretical Biology 46 255-270. (doi:10.1016/0022-5193(74)90151-9)

Furbee JW Jr \& Fless GM 1996 Evaluation of common electrophoretic methods in determining the molecular weight of apolipoprotein(a) polymorphs 3. Analytical Biochemistry 234 66-73. (doi:10.1006/abio. 1996.0051)

Grandy DK 2007 Trace amine-associated receptor 1 - family archetype or iconoclast? Pharmacology and Therapeutics 116 355-390. (doi:10.1016/j. pharmthera.2007.06.007)

Hart ME, Suchland KL, Miyakawa M, Bunzow JR, Grandy DK \& Scanlan TS 2006 Trace amine-associated receptor agonists: synthesis and evaluation of thyronamines and related analogues. Journal of Medicinal Chemistry 49 1101-1112. (doi:10.1021/jm0505718)

Hoefig CS, Schlärmann P, Piehl S, Bertoldi M, Scanlan TS, Schweizer U \& Kohrle J 2009 Towards the indentification of iodothyronine decarboxylases. Acta Medica Portuguesa, Abstracts of the 34th Annual meeting of the European Thryoid Association (P139) 1(22), 99.

Ianculescu AG, Giacomini KM \& Scanlan TS 2009 Identification and characterization of 3-iodothyronamine intracellular transport. Endocrinology 150 1991-1999. (doi:10.1210/en.2008-1339)

Klieverik LP, Sauerwein HP, Ackermans MT, Boelen A, Kalsbeek A \& Fliers E 2008 Effects of thyrotoxicosis and selective hepatic autonomic denervation on hepatic glucose metabolism in rats. American Journal of Physiology. Endocrinology and Metabolism 294 E513-E520. (doi:10.1152/ ajpendo.00659.2007)
Klieverik LP, Foppen E, Ackermans MT, Serlie MJ, Sauerwein HP, Scanlan TS, Grandy DK, Fliers E \& Kalsbeek A 2009 Central effects of thyronamines on glucose metabolism in rats. Journal of Endocrinology 201 377-386. (doi:10.1677/JOE-09-0043)

Meischl C, Buermans HP, Hazes T, Zuidwijk MJ, Musters RJ, Boer C, van Lingen A, Simonides WS, Blankenstein MA, Dupuy C et al. 2008 $\mathrm{H} 9 \mathrm{c} 2$ cardiomyoblasts produce thyroid hormone 1 . American Journal of Physiology. Cell Physiology 294 C1227-C1233. (doi:10.1152/ajpcell. 00328.2007)

Obregon MJ, Mallol J, Escobar del RF \& Morreale de EG 1981 Presence of L-thyroxine and 3,5,3'-triiodo-L-thyronine in tissues from thyroidectomized rats. Endocrinology 109 908-913. (doi:10.1210/endo109-3-908)

Panas HN, Lynch LJ, Vallender EJ, Xie Z, Chen GL, Lynn SK, Scanlan TS \& Miller GM 2010 Normal thermoregulatory responses to 3-iodothyronamine, trace amines and amphetamine-like psychostimulants in trace amine associated receptor 1 knockout mice. Journal of Neuroscience Research 88 1962-1969. (doi:10.1002/jnr.22367)

Piehl S, Heberer T, Balizs G, Scanlan TS \& Kohrle J 2008a Development of a validated liquid chromatography/tandem mass spectrometry method for the distinction of thyronine and thyronamine constitutional isomers and for the identification of new deiodinase substrates. Rapid Communications in Mass Spectrometry 22 3286-3296. (doi:10. $1002 / \mathrm{rcm} .3732)$

Piehl S, Heberer T, Balizs G, Scanlan TS, Smits R, Koksch B \& Kohrle J $2008 b$ Thyronamines are isozyme-specific substrates of deiodinases. Endocrinology 149 3037-3045. (doi:10.1210/en.2007-1678)

Pietsch CA, Scanlan TS \& Anderson RJ 2007 Thyronamines are substrates for human liver sulfotransferases. Endocrinology $\mathbf{1 4 8}$ 1921-1927. (doi:10.1210/en.2006-1172)

Regard JB, Kataoka H, Cano DA, Camerer E, Yin L, Zheng YW, Scanlan TS, Hebrok M \& Coughlin SR 2007 Probing cell type-specific functions of $G_{i}$ in vivo identifies GPCR regulators of insulin secretion. Journal of Clinical Investigation 117 4034-4043. (doi:10.1172/JCI32994)

Scanlan TS 2009 Minireview: 3-iodothyronamine ( $\left.T_{1} A M\right)$ : a new player on the thyroid endocrine team? Endocrinology 150 1108-1111. (doi:10.1210/en.2008-1596)

Scanlan TS, Suchland KL, Hart ME, Chiellini G, Huang Y, Kruzich PJ, Frascarelli S, Crossley DA, Bunzow JR, Ronca-Testoni S et al. 2004 3-Iodothyronamine is an endogenous and rapid-acting derivative of thyroid hormone. Nature Medicine 10 638-642. (doi:10.1038/ nm1051)

Tan ES, Naylor JC, Groban ES, Bunzow JR, Jacobson MP, Grandy DK \& Scanlan TS 2009 The molecular basis of species-specific ligand activation of trace amine-associated receptor 1 (TAAR ${ }_{1}$ ). ACS Chemical Biology 4 209-220. (doi:10.1021/cb800304d)

Taurog A \& Evans ES 1967 Extrathyroidal thyroxine formation in completely thyroidectomized rats. Endocrinology 80 915-925. (doi:10. 1210/endo-80-5-915)

Wood WJ, Geraci T, Nilsen A, DeBarber AE \& Scanlan TS 2009 Iodothyronamines are oxidatively deaminated to iodothyroacetic acids in vivo. Chembiochem : a European Journal of Chemical Biology 10 361-365. (doi:10.1002/cbic.200800607)

Zucchi R, Ghelardoni S \& Chiellini G 2008 Cardiac effects of thyronamines. Heart Failure Reviews 15 171-176. (doi:10.1007/ S10741-008-9120-z)

Received in final form 28 June 2010

Accepted 5 July 2010

Made available online as an Accepted Preprint 5 July 2010 